Prevalence of asthma

\section{Asthma prevalence in adults: good news?}

\section{S K Weiland, N Pearce}

\section{Time trends in asthma prevalence may have levelled off}

$\mathrm{F}$ ew diseases have a relation to age which is as fascinating and complex as for asthma. It is a chronic but not necessarily lifelong condition. The incidence of asthma and wheezing illness peaks in very early childhood, but new incident cases occur throughout life. ${ }^{1-4}$ In many affected subjects, particularly children, it disappears after some time. ${ }^{2-4}$ However, in a substantial proportion of cases which have apparently lost the disease it will come back, often after many years. ${ }^{3}{ }^{4}$ Another intriguing feature is that the sex ratio changes with age. Most studies show that boys are affected more often by wheezing illnesses than girls, but this sex ratio usually reverses during or shortly after puberty, partly due to a higher incidence in females. ${ }^{5-9}$

Most studies investigating the relationship between age and asthma have been performed in infants and children and, in fact, different age related phenotypes in childhood have been described which seem to have distinct causes and consequences. ${ }^{210}$ Information on the relation to age in adults is scarce and has often been based on routine data or cross sectional studies. ${ }^{16}$

In this issue of Thorax Chinn and colleagues report the findings of phase II of the European Community Respiratory Health Survey (ECRHS) which involved following more than 11000 randomly selected adults (participants in ECRHS phase I stage 2 at which time they were aged 20-44 years) for a period of 5-11 years. ${ }^{11}$ The investigators used the same standardised questionnaires at the start and end of the observation period, asking about the occurrence and severity of respiratory symptoms in the 12 months before the survey. The study is unique because of its international approach which included 29 study centres from 14 countries. Consistency of findings across countries argues strongly for the validity of the results.

Nevertheless, there are several methodological issues that should be considered before accepting the findings as valid. In particular, measuring asthma in populations is no easy task. ${ }^{12}$ There is no single simple instrument by which cases can be identified. Instead, there is a whole battery of different measures, all of which have advantages and disadvantages. Chinn et al ${ }^{11}$ report data collected by standardised symptom based questionnaires which are considered to be the standard method for measuring the prevalence of asthma in epidemiological studies. ${ }^{12}$ However, since these do not measure the prevalence of asthma in individuals with complete accuracy, changes within individuals between repeated surveys may reflect measurement error rather than genuine changes in morbidity. Chinn et al therefore report the "net change" in symptom status for each centre rather than reporting separately the rate at which previously disease free subjects became symptomatic (incidence) and the rate at which previously diseased subjects became asymptomatic (remission). While this approach is perhaps regrettable from a clinical point of view, it is methodologically valid and provides findings that are of considerable interest.

The study showed no increase in the 12 month period prevalence of wheeze and more severe asthma symptoms during the follow up period which averaged about 8 years. However, there was a significant increase in the reported 12 month period prevalence of attacks, labelled as "asthma attacks", and in the point prevalence of asthma medication use and nasal allergies.

How can these apparently contradictory patterns be reconciled? An increased prevalence of asthma attacks and medication use could be due to an increase in the prevalence of severe asthma, in recognition of symptoms by patients, in diagnostic labelling of wheezing illness by physicians, or in medical treatment of the condition. Each of these, in turn, could reflect temporal trends (changes over time) or age effects (changes with increasing age). However, Chinn et al also measured the prevalence of wheeze and severe asthma symptoms and these did not increase. It is therefore most likely that the observed increases reflect changes in diagnostic labelling and/or medical treatment for mild and/or moderate asthma.

Although the study by Chinn et al does not allow to disentangle potential age and period effects, it is interesting to review the current evidence for time trends in asthma prevalence. An increase in the prevalence of asthma and allergies in the late 20th century is generally accepted. While most studies reported increases in the prevalence of symptoms and diagnoses (and these are mostly in children), these observations are supported by studies which also included physiological markers. ${ }^{13}$ Recently, however, several studies have suggested that this increase may have come to an end-at least in some areas.

A study in adults over the period from 1972 to 1998 still observed increases in the prevalence of asthma symptoms and diagnoses which was more pronounced among those aged less than 40 years. ${ }^{14}$ Two other studies on adults examining time trends during the 1990s, however, found no increase in the prevalence of either asthma symptoms ${ }^{15}$ or bronchial hyperresponsiveness, ${ }^{16}$ but an increase in the prevalence of reported asthma diagnoses. An investigation of Swiss adolescents observed no further increase in the prevalence of asthma symptoms and allergic sensitisation in the late 1990s. ${ }^{17}$ Finally, Anderson et al, ${ }^{18}$ in a large survey in the UK, actually found a decrease in the prevalence of symptoms of asthma, hay fever, and eczema in 1214 year olds between 1995 and 2002. During the same period there was an increase in the lifetime prevalence of diagnoses of the three disease entities under investigation. Robertson et a ${ }^{19}$ reported a similar reduction in the prevalence of asthma in children in Melbourne during 1993-2004. Thus, there is evidence from several countries that time trends in the burden from asthma may have levelled off-in some countries even reversed-while the rate of reported diagnoses continued to increase. It is important to note, however, that these reports come mostly from high income countries with prevalence rates ranking among the highest in the world. ${ }^{20}$ The global burden of asthma, however, will be determined to a large extent also by what happens in low income countries. In this respect, the upcoming results of phase III of the International Study of Asthma and Allergies in Childhood (ISAAC), which has studied recent time trends in about 100 centres worldwide (including those of Anderson $e t a l^{18}$ and Robertson $e t a l^{19}$ ), will be of particular interest. ${ }^{21}$

If, in fact, time trends in asthma prevalence have levelled off, it is not clear which factors have determined this change. It is possible that the increase in asthma prevalence has reached a natural plateau in English speaking countries in which virtually all the "susceptibles" may have developed the 
condition. However, this speculation would not explain the apparent decrease in some countries. In this regard, it is likely that improved medical treatment, especially the use of inhaled steroids, has contributed. ${ }^{16}$ It has been argued that many patients do not benefit from new treatment because their disease is not diagnosed and/or treated adequately. ${ }^{22}$ In this sense, the increased prevalence of diagnosed asthma reported by Chinn et al, in the absence of an increased symptom prevalence, could also be a reflection that medical care of asthma patients has changed for the better. Whatever the explanation, the findings of Chinn et al are in line with those of other recent studies and may, in fact, be good news.

Thorax 2004;59:637-638.

doi: $10.1136 /$ thx.2004.026302

\section{Authors' affiliations}

S K Weiland, Department of Epidemiology, University of Ulm, Ulm, Germany N Pearce, Centre for Public Health Research, Research School of Public Health, Massey University Wellington Campus, New Zealand

Correspondence to: Prof Dr med S K Weiland, MSc, Department of Epidemiology, University of Ulm, Helmholzstr. 22,89081Ulm, Germany; stephan.weiland@medizin.uni-ulm.de

The Centre for Public Health Research is supported by a Programme Grant from the Health Research Council of New Zealand.

\section{REFERENCES}

1 Yunginger JW, Reed CE, O'Connell EJ, et al. A community-based study of the epidemiology of asthma. Incidence rates, 1964-1983. Am Rev Respir Dis 1992;146:888-94

2 Martinez FD, Wright AL, Taussig LM, et al. Asthma and wheezing in the first six years of life: the Group Health Medical Associates. NEngl J Med 1995:332:133-8.

3 Strachan DP, Butland BK, Anderson HR. Incidence and prognosis of asthma and wheezing illness from early childhood to age 33 in a national British cohort. BMJ 1996:312:1195-9.

4 Sears MR, Greene JM, Willan AR, et al. A longitudinal, population-based, cohort study of childhood asthma followed to adulthood. N Engl J Med 2003;349:1414-22.

5 Nicolai T, Pereszlenyiova-Bliznakova L, Illi S, et al. Longitudinal follow-up of the changing gender ratio in asthma from childhood to adulthood: role of delayed manifestation in girls. Pediatr Allergy Immunol 2003:14:280-3.

6 Health Survey for England 2001. Respiratory symptoms, atopic conditions and lung function. http://www. official-documents.co.uk/document/ deps/doh/survey01/rsac/rsac.htm (status May 2004).

7 de Marco R, Locatelli F, Sunyer J, et al. Differences in incidence of reported asthma related to age in men and women. A retrospective analysis of the data of the European Respiratory Health Survey. Am J Respir Crit Care Med 2000;162:68-74.

8 De Marco R, Locatelli F, Cerveri I, et al. Italian Study on Asthma in Young Adults study group. Incidence and remission of asthma: a retrospective study on the natural history of asthma in Italy, J Allergy Clin Immunol 2002;110:228-35.

9 Eagan TM, Bakke PS, Eide GE, et al. Incidence of asthma and respiratory symptoms by sex, age and smoking in a community study. Eur Respir J. 2002;19: 599-605 (erratum, 2003:21:735).

10 Stein RT, Martinez FD. Asthma phenotypes in childhood: lessons from an epidemiological approach. Paediatr Respir Rev 2004;5:155-61.

11 Chinn S, Jarvis D, Burney P, et al. Increase in diagnosed asthma but not in symptoms in the European Community Respiratory Health Survey. Thorax 2004;59:646-51.
12 Pekkanen J, Pearce N. Defining asthma in epidemiological studies. Eur Respir $J$ 1999;14:951-7

13 Wieringa MH, Vermeire PA, Brunekreef $B$, et al. Increased occurrence of asthma and allergy: critical appraisal of studies using allergic sensitization, bronchial hyper-responsiveness and lung function measurements. Clin Exp Allergy 2001;31:1553-63.

14 Brogger J, Bakke P, Eide GE, et al. Long-term changes in adult asthma prevalence. Eur Respir J 2003;21:468-72.

15 Verlato G, Corsico A, Villani S, et al. Is the prevalence of adult asthma and allergic rhinitis still increasing? Results of an Italian study. $J$ Allergy Clin Immunol 2003;1 11:1232-8.

16 Barraclough R, Devereux G, Hendrick DJ, et al. Apparent but not real increase in asthma prevalence during the 1990s. Eur Respir J 2002;20:826-33.

17 Braun-Fahrlander C, Gassner M, Grize L, et al Swiss Study on Childhood Allergy and

Respiratory symptoms; Air Pollution (SCARPOL) team. No further increase in asthma, hay fever and atopic sensitisation in adolescents living in Switzerland. Eur Respir J 2004;23:407-13.

18 Anderson HR, Ruggles R, Strachan DP, et al. Trends in prevalence of symptoms of asthma, hay fever, and eczema in 12-14 year olds in the British Isles, 1995-2002: questionnaire survey. BMJ 2004;328:1052-3.

19 Robertson CF, Roberts MH, Kappers JH. Asthma prevalence in Melbourne schoolchildren: have we reached the peak? Med J Aust 2004; 180:273-6.

20 International Study of Asthma and Allergies in Childhood (ISAAC) Steering Committee.

Worldwide variation in prevalence of symptoms of asthma, allergic rhinoconjunctivitis, and atopic eczema: ISAAC. Lancet 1998;351:1225-32.

21 Asher MI, Keil U, Anderson HR, et al. International Study of Asthma and Allergies in Childhood (ISAAC): rationale and methods. Eur Respir J 1995;8:483-91.

22 Rabe KF, Vermeire PA, Soriano JB, et al. Clinical management of asthma in 1999: the Asthma Insights and Reality in Europe (AIRE) study. Eur Respir J 2000;16:802-7.

23 Kips JC, Pauwels RA. Asthma control: where do we fail? Eur Respir J 2000;16:797-8.

that the form of oxygen most commonly prescribed in the UK lacks such an agreed evidence base. Short burst oxygen use for the palliation of dyspnoea is fairly widespread among patients with severe COPD. ${ }^{2}$ Anecdotally, it is beloved by them and often given at their request by respiratory specialists and general practitioners when other options have been exhausted. When it is given there is some evidence that it is used inconsistently ${ }^{4}$ - either before or after exercise-and that the delivery mode is nonstandardised with both face masks and nasal cannulae being used with flow rates set usually at 2 or $4 \mathrm{l} / \mathrm{min}$, but often left to the discretion of the nonspecialist or patient to determine.

This sounds like a mess that needs sorting out and it is notable that the initial British Thoracic Society, American Thoracic Society, ${ }^{6}$ and European Respiratory Society ${ }^{7}$ management guidelines for COPD had little to say on this subject. More disappointingly, the contemporary GOLD $^{8}$ document virtually ignores short burst oxygen and recommendations from the 2004 NICE guideline ${ }^{9}$ consist of rather vague statements based on levels $\mathrm{C}$ and D evidence. Although this 
perceived paucity of an historical evidence base has previously precluded authoritative guidance, a number of contemporary studies examining the effectiveness of short burst oxygen therapy are now available for us to analyse. The problem for the jobbing clinician is that the available evidence has yet to be synthesised into a whole and, practically, this is a challenging exercise for a number of reasons evident on review of the literature.

\section{REVIEW OF THE EVIDENCE}

Perhaps the best evidence for a positive effect of short burst oxygen therapy in exercise for subjects with COPD comes from a single paper published some years ago. Woodcock et al ${ }^{10}$ showed that pre-dosing with oxygen for as little as 5 minutes at a rate of $4 \mathrm{l} / \mathrm{min}$ using nasal cannulae before both a submaximal treadmill test and a 6 minute walk test increased walking distance compared with administered air in COPD subjects. Dyspnoea, however, was reduced only for the shorter treadmill test and not for the 6 minute test. The subjects were not severely hypoxic at rest and real time oxygen saturation was not measured.

Two further papers provide borderline positive findings. Evans et al $^{11}$ studied 19 hypoxic subjects with severe COPD of mean age 65 years. Subjects undertook three simulated step tests breathing via a face mask, $67 \%$ oxygen, $10 \mathrm{l} / \mathrm{min}$ compressed air, or room air with no mask. Breathing oxygen after exercise was associated with a shortened dyspnoea recovery time from 3.6 minutes to 3.0 minutes. This study is remarkable because it is one of only two cited in the literature that has specifically tested the reproducibility of patient discrimination between oxygen and air. Little consistency was found after a time interval and the authors concluded that, despite the reduction in recovery time observed in the first part of the trial, the poor reproducibility of this finding cast doubt on the justification for short burst therapy following exercise.

Most recently, Killen and Corris ${ }^{12}$ reported in this journal the use of short burst oxygen given either before or after stair climbing in 18 subjects with COPD. Air or oxygen was delivered for 5 minutes at a rate of $2 \mathrm{l} / \mathrm{min}$ via a face mask before and after ascending stairs in subjects who desaturated on exercise. Three combinations were provided of air and air, air then oxygen, or oxygen then air. Although there was no statistical difference in dyspnoea scores between these three groups, a statistically significant difference in dyspnoea was seen (visual analogue score of $7 \mathrm{~mm}$ ) when the oxygen subgroups were combined compared with those breathing air. Recovery times were not measured. The authors suggest that this level of dyspnoea reduction represented a significant benefit of short burst oxygen therapy.

One further paper which deserves comment is that of Swinburn et al..$^{13}$ This study also found a reduction in the dyspnoea score in 12 subjects with severe COPD at rest breathing 28\% oxygen via a face mask compared with compressed air at the same flow rate. Visual analogue scores reduced from $46 \mathrm{~mm}$ on air to $30 \mathrm{~mm}$ on oxygen. The subjects were asked repeatedly when blinded if they felt better breathing air or oxygen by mask compared with room air; compressed air helped in 15 of 24 occasions tested and oxygen in 22 of 24. Although often quoted as a study supporting short burst oxygen therapy, it must be noted that the subjects were tested at rest and the effects of exertion were not studied.

While these studies at best provide evidence of partial benefit, there is inconsistency in the subject groups, exercise performed, and outcome measures. Moreover, there are other studies with distinctly negative results. McKeon et al ${ }^{14}$ examined the effect of predosing with air or oxygen at a rate of $2.5 \mathrm{l} / \mathrm{min}$ via nasal cannulae prior to a treadmill exercise test in 20 subjects with COPD (mean $\mathrm{FEV}_{1}$ $31 \%$ predicted). No effect was observed on the dyspnoea score during exercise. Rhind et $a l^{15}$ presented similar findings in 12 subjects with COPD.

More recently, Nandi et al ${ }^{16}$ reported the effect of both predosing for $10 \mathrm{~min}$ utes with either $28 \%$ oxygen by face mask or compressed air at a rate of $4 \mathrm{l} / \mathrm{min}$ and also post exercise dosing with similarly blinded gas mixtures. Six minute walk tests were undertaken and oxygen was found to have no benefit compared with compressed air in terms of relief of dyspnoea in either arm of the study in the 34 subjects included (mean $\mathrm{FEV}_{1} 34 \%$ predicted). All of these subjects had significant oxygen desaturation. In a not dissimilar study Lewis et $a l^{17}$ also used the 6 minute walk test to study 22 patients with COPD (mean $\mathrm{FEV}_{1} 34 \%$ predicted) without resting hypoxia but most of whom desaturated on exercise. In this study the gas mixture was administered for 5 minutes at a flow rate of $2 \mathrm{l} / \mathrm{min}$ via nasal cannulae. No effect was observed on the dyspnoea score with either pre or post dosing with oxygen compared with compressed air.

In contrast to these at best equivocal and conflicting results, there is a clearer-although by no means perfect-consensus on the use of ambulatory oxygen therapy as an adjunct to reducing dyspnoea and improving exer- cise tolerance. A number of studies have reported benefits, ${ }^{18-20}$ although not in all subjects. ${ }^{21}$ The mechanism for this apparent reduction in dyspnoea is postulated as the reduced work of breathing when hypoxaemia is prevented or reduced in severity. ${ }^{22}$ So why is oxygen helpful in the ambulatory setting but of less value following exercise? One key element of the increased work of breathing in patients with limited expiratory flow is the development of dynamic hyperinflation.

\section{STUDY BY STEVENSON AND CALVERLEY}

It is argued by Stevenson and Calverley ${ }^{1}$ in this issue of Thorax that a reduction in dynamic hyperinflation may hold the key to the successful identification of those subjects who will benefit from oxygen and, specifically in this study, those using it as a short burst dosing intervention following exercise.

Stevenson and Calverley administered oxygen at an inspired oxygen fraction of 0.4 or air at a similar flow rate ( $10 \mathrm{l} / \mathrm{min})$ to 18 moderately severe COPD patients $\left(\mathrm{FEV}_{1} 40 \%\right.$ predicted $)$ after standardised exercise. In this study subjects exercised both "instrumented" in a full cardiorespiratory exercise test breathing via a mouthpiece and "noninstrumented" breathing from a face mask. The hypothesis tested was that oxygen administration should reduce the work of breathing and aid resolution of dynamic hyperinflation by reducing tidal volume breathing and allowing an increased expiratory time. Administration of oxygen after exercise was associated with a reduced ventilatory effort and more rapid resolution of dynamic hyperinflation but no significant reduction in dyspnoea. The findings were essentially negative in that, although observed changes occurred, these did not produce a significant reduction in breathlessness as measured by a Borg scale when oxygen administration was compared with that of air. A significant difference in recovery time of dyspnoea was noted, however, between the instrumented mouthpiece tests (11.38 (1.49) minutes) and those when face masks alone were used (7.94 (1.12) minutes).

The study by Stevenson and Calverley adds to the evidence that there is no single easily measured mechanism by which oxygen reduces dyspnoea after exercise, and that the mechanisms which may operate to prevent dyspnoea when oxygen is administered during exercise may not be the same as those which may operate in influencing dyspnoea after exercise. The authors point out that the reduced recovery time observed in the subjects when receiving 
oxygen by face mask may reflect stimulation of facial receptors that could reduce dyspnoea perception. ${ }^{23}$ Even this suggestion is contentious in the context of clinical use of short burst oxygen after exercise. The best evidence for a positive effect of oxygen was derived from a study using nasal cannulae rather than masks, ${ }^{10}$ and a recent study examining the effect of mask versus room air breathing concluded that any apparent benefit is an order effect of exercise rather than a result of either oxygen or delivery apparatus. ${ }^{24}$

\section{CLINICAL IMPLICATIONS}

The difficulty for those trying to develop guidelines in this arena is the disparate nature of these studies. In some the study end points were dyspnoea and in others exercise tolerance; the nature and duration of exercise was different; the inspired oxygen tensions, flow rates and delivery systems were not standardised; and perhaps most challenging of all were the settings for the studies. Finally, as clinicians we must ask practical questions-are the study subjects included the ones we would consider recommending for short burst oxygen therapy and are the study circumstances those in which patients commonly use this form of oxygen?

What we may deduce so far is that short burst oxygen therapy either before or after exercise probably does not benefit the majority of patients with moderately severe COPD who exercise for more than a very short period of time. Before comprehensive recommendations can be made we still require specific studies to re-evaluate the work of Swinburn ${ }^{13}$ and Killen ${ }^{12}$ in subjects at rest and after very short episodes of exertion set in the circumstances of everyday living.

doi: $10.1136 /$ thx.2003.017301 Department of Respiratory Medicine, Whipps Cross University Hospital, London E1 1 1NR; Michael.Roberts@whippsc.nhs.uk

\section{REFERENCES}

1 Stevenson NJ, Calverley PMA. Effect of oxygen on recovery from maximal exercise in patients with chronic obstructive pulmonary disease. Thorax 2004;59:668-72.

2 Okubadejo AA, Paul EA, Wedzicha JA. Domiciliary oxygen cylinders: indications, prescription and usage. Respir Med 1994;88:777-85.

3 Anon. UK prescription pricing authority annual report 2001 ;2:54-5. http://www.ppa.org.uk/ index.htm (accessed 22 April 2003)

4 Jones MM, Harvey JE, Tattersfield AE. How patients use domiciliary oxygen BMJ 1978;1 1397-400.

5 COPD Guidelines Group of the Standards of Care Committee of the BTS. British Thoracic Society guidelines for the management of chronic obstructive pulmonary disease. Thorax 1997;52(Suppl 5):S5.

6 American Thoracic Society. Standards for the diagnosis and care of patients with chronic obstructive pulmonary disease. Am J Respir Crit Care Med 1995;152:S77-121.

7 Siafakas NM, Vermeire P, Pride NB, et al. Optimal assessment and management of chronic obstructive pulmonary disease (COPD). The European Respiratory Society Task Force. Eur Respir J 1995;8:1398-420.

8 National Heart, Lung and Blood Institute/World Health Organization. Global strategy for the diagnosis, management, and prevention of chronic obstructive pulmonary disease: NHLBI/ WHO workshop, 2003. http:// www.goldcopd.com/workshop/toc.html.

9 National Collaborating Centre for Chronic Conditions. National clinical guideline on management of chronic obstructive pulmonary disease in adults in primary and secondary care. Thorax 2004;59(Suppl I): 1-232.

10 Woodcock AA, Gross ER, Geddes DM. Oxygen relieves breathlessness in 'pink puffers'. Lancet $1981 ; \mathrm{i}: 907-9$
Thorax 2004;59:638-640.

Correspondence to: $\operatorname{Dr} C M$ Roberts,

11 Evans TW, Waterhouse JC, Carter A, et al. Short burst oxygen for breathlessness in chronic obstructive airway disease. Thorax 1986:41:611-5.

12 Killen JW, Corris PA. A pragmatic assessment of the placement of oxygen when given for exercise induced dyspnoea. Thorax 200, 55:544-6.

13 Swinburn CR, Mould H, Stone TN, et al. Symptomatic benefit of supplemental oxygen in hypoxemic patients with chronic lung disease. Am Rev Respir Dis 1991;143:913-5.

14 McKeon KL, Murree-Allen K, Saunders NA. Effects of breathing supplemental oxygen before progressive exercise in patients with chronic obstructive lung disease. Thorax 1988;43:53-6.

15 Rhind C, Prince K, Scott W, et al. Symptomatic oxygen therapy in hypoxic chronic bronchitis. Thorax 1986;41:245.

16 Nandi K, Smith AA, Crawford A, et al. Oxygen supplementation before or after submaximal exercise in patients with chronic obstructive pulmonary disease. Thorax 2003:58:670-3.

17 Lewis CA, Eaton TE, Young P, et al. Short-burst oxygen immediately before and after exercise is ineffective in non-hypoxic COPD patients. Eur Respir J 2003;22:584-8.

18 Davidson AC, Leach R, George RJD, et al. Supplemental oxygen and exercise ability in chronic obstructive airways disease. Thorax 1988:43:965-71.

19 Dean NC, Brown JK, Himelman RB, et al. Oxygen may improve dyspnea and endurance in patients with chronic obstructive pulmonary disease and only mild hypoxemia. Am Rev Respir Dis 1992;146:941-5.

20 Eaton T, Garrett JE, Young W, et al. Ambulatory oxygen improves quality of life of COPD patients: a randomized controlled study. Eur Respir J 2002;20:306-12.

21 Leach RM, Davidson AC, Chinn S, et al. portable liquid oxygen and exercise ability in severe respiratory disability. Thorax 1992;47:781-9.

22 Lane R, Cockcroft A, Adams L, et al. Arterial oxygen saturation and breathlessness during exercise in patients with chronic obstructive airways disease. Clin Sci 1987;72:693-8.

23 Spence DP, Graham DR, Ahmed J, et al. Does cold air affect exercise capacity and dyspnoea in stable chronic obstructive pulmonary disease? Chest 1993;103:693-6.

24 Marques-Magallanes JA, Storer TW, Cooper CB. Treadmill exercise duration and dyspnea recovery time in chronic obstructive pulmonary disease: effects of oxygen breathing and repeated testing. Respir Med 1999;93:71-2.

ify the underlying immunological predisposition to the disease.

Asthma is widely recognised as an inflammatory airway disease driven by activation of Th2-type T lymphocytes in both atopic allergic and intrinsic or nonallergic forms. ${ }^{3-5}$ Recent advances in our understanding of the control of the immunological process have identified regulatory suppressive $\mathrm{T}$ cells which can prevent activation of self-reactive or pathological $\mathrm{T}$ cells in autoimmune or infectious disease models. ${ }^{6-8}$ Does this understanding of immune regulation hold the prospect of disease control or even prevention for asthma?

\section{MECHANISM OF ACTION}

M uch is currently made of the control of asthma in therapeutic guidelines. Both the British guidelines and the Global Initiative for Asthma (GINA) define measures of control of the disease, and recent studies have defined strategies for control using available anti-inflammatory and bronchodilator therapy such as inhaled steroids and long acting $\beta_{2}$ agonists. ${ }^{12}$ However, currently available treatments suppress inflammation but do not mod-
The interest of immunologists in actively suppressive $\mathrm{T}$ cells was reawoken by the finding by Sakaguchi and co-workers that depletion of CD4+CD25+ T lymphocytes from mice led to development of autoimmune 
pathology which could be prevented by re-introduction of these cells. ${ }^{9}$ Such CD4+CD25+ regulatory $\mathrm{T}$ cells were active in many disease models and could reverse established inflammatory diseases such as colitis. ${ }^{10}$ These cells were shown to arise by high affinity selection in the thymus and are thought to form a "naturally occurring" regulatory population that is an important part of maintenance of tolerance or non-reactivity of the immune system against itself. ${ }^{11}{ }^{12}$ Shevach and co-workers established an in vitro system and showed that $\mathrm{CD} 4+\mathrm{CD} 25+\mathrm{T}$ cells failed to proliferate to polyclonal or antigenic stimulation in culture; furthermore, they could suppress proliferation and cytokine production by $\mathrm{CD} 4+\mathrm{CD} 25-\mathrm{T}$ cells. ${ }^{13}$ This system showed that human peripheral blood CD4+CD25+ T cells also represent a non-proliferating suppressive T cell population. ${ }^{14-19}$ The mechanism of suppression by CD4+CD25+ regulatory $\mathrm{T}$ cells remains unclear: in some in vivo models suppression is dependent on the immunosuppressive cytokines interleukin 10 (IL-10) and transforming growth factor $\beta$ (TGF $\beta$ ), whereas suppressive activity in vitro is not affected by the absence or neutralisation of these factors. ${ }^{7}$ In vitro suppression by both mouse and human CD4+CD25+ $\mathrm{T}$ cells requires contact between regulating and responding cells and is partly dependent on negative costimulatory signals including CTLA4 and PD-1.7 As CD25 is the alpha chain of the IL-2 receptor and these cells do not make their own IL-2, one possibility is that regulation occurs through competition for this and other $\mathrm{T}$ cell growth factors as well as by competition for "space" in repopulation experiments in lymphopenic mice. ${ }^{20}$ Since CD4+CD25+ $\mathrm{T}$ cells could regulate non-T cell dependent colitis in a mouse model, such interactions with responder $\mathrm{T}$ cells cannot be the sole mode of suppression and regulatory $\mathrm{T}$ cells are likely to influence cells of the innate immune system including dendritic cells. ${ }^{21}$ Can CD4+CD25+ T cells inhibit activation of Th2 cells in animal models or in vitro?

\section{Animal models}

Animal models of allergic airway sensitisation have been useful in defining potential immunological mechanisms in asthma and allergic disease. ${ }^{22}$ However, there are few data on CD4+CD25+ T cell regulation of mouse Th2 airway inflammation and airway hyperresponsiveness. When CD4+CD25+ T cells were depleted in one model airway, inflammation actually decreased. ${ }^{23}$ This may be because CD25 is also a marker of recently activated $\mathrm{T}$ cells or memory effector cells, so both regulators and effectors had been removed. However, co-transfer of ex vivo expanded CD4+CD25+ ovalbumin specific $T$ cells together with Th2 cells had no effect on subsequent inhaled ovalbumin challenge in another mouse model, ${ }^{24}$ and ovalbumin specific airway CD4+CD25+ $\mathrm{T}$ cells in another complex double transgenic model reduced airway inflammation but not airway hyperresponsiveness in response to inhaled challenge. ${ }^{25}$

\section{In vitro experiments}

Human peripheral blood CD4+CD25+ $\mathrm{T}$ cells were shown to be suppressive in allergen stimulated cultures. ${ }^{26-28}$ We recently compared such suppressive activity in allergen stimulated in vitro cultures of CD4+CD25- and CD4+CD25+ $\mathrm{T}$ cells from non-atopic and atopic volunteers. CD4+CD25+ T cells suppressed proliferation and cytokine production by CD4+CD25- from non-atopic subjects almost completely, but this suppressive activity was significantly reduced in cultures from atopic volunteers, particularly when blood was taken from hay fever sufferers during the height of the pollen season. ${ }^{28}$ Interestingly, removal of CD4+CD25+ T cells from peripheral blood of nonatopic individuals revealed proliferation and Th2 cytokine production to allergen stimulation which was similar to that from atopic volunteers. These data led to the suggestion that Th2 responses to allergen in non-atopic subjects may be actively suppressed by CD4+CD25+ T cells, and that this regulation is either deficient in atopic subjects or overcome by allergen exposure. Clearly, further work is required to determine whether such regulatory cells occur in the airway or are reduced in asthma.

Although CD4+CD25+ regulatory $\mathrm{T}$ cells have been isolated from lung tissue around lung cancers, ${ }^{29}$ phenotypic identification of regulatory $\mathrm{T}$ cells is hampered by the lack of a specific cell marker. One important advance in understanding the regulatory function of these cells came from studies of a rare human immunodefiency (IPEX) which results in autoimmune and allergic disease and its murine counterpart, the "scurfy" mouse strain: both were shown to result from mutation of a transcription factor termed FoxP3.. ${ }^{31}$ Furthermore, in elegant experiments FoxP3 knockout mice were shown to lack $\mathrm{CD} 4+\mathrm{CD} 25+$ regulatory $\mathrm{T}$ cells, whereas ectopic expression of the transcription factor by retroviral transfer into $\mathrm{CD} 4+\mathrm{CD} 25-\mathrm{T}$ cells rendered these regulatory. ${ }^{32-34}$ How FoxP3 influences suppression is unclear, and although we and others have confirmed relative overexpression of mRNA for FoxP3 by human $\mathrm{CD} 4+\mathrm{CD} 25+\mathrm{T}$ cells, ${ }^{28}$ this may not represent a specific marker for this cell type ${ }^{35}$ nor does it appear to be active in suppression by other regulatory $\mathrm{T}$ cell subtypes. Recently, neuropilin-1 was identified as a potential surface marker for mouse CD4+CD25+ T cells. ${ }^{36}$

It is therefore possible that atopy (and asthma) result from a failure to suppress inappropriate Th2 responses to environmental allergens. What factors determine the balance between regulatory and potentially immunopathogical Th2 responses to allergen exposure in the developing (or mature) immune system? Increasing interest has focused on the mode of activation of the innate immune system (including airway dendritic cells) as a major determinant of the type of $\mathrm{T}$ cell response to antigen exposure. As well as the route, dose and frequency of antigen exposure, co-activation of pattern recognition receptors such as Toll-like receptors (TLR) or COstimulatory molecules act as important determinants of $\mathrm{T}$ cell activation. ${ }^{37}$ It is possible that relative levels of activation of these receptors may be relevant-for example, low dose bacterial lipopolysaccharide (LPS) acting through TLR4 favours Th2 development ${ }^{38}$ whereas higher doses drive Thl development and exposure of dendritic cells to LPS can overcome regulation by CD4+CD25+ T cells. ${ }^{39}{ }^{40}$ Similarly, the balance of costimulation may be important as ICOS co-stimulation is active in supporting Th2 responses but can also drive development of IL-10 producing regulatory $\mathrm{T}$ cells in the mouse lung. ${ }^{41}$ Such considerations may provide an immunological basis for the hygiene hypothesis for the increasing prevalence of asthma and allergic disease: this may represent a failure of development of appropriate regulatory responses due to lack of appropriate TLR or co-stimulator activation at the time of allergen exposure. ${ }^{42}$ It may also underlie some of the genetic associations of asthma as with TLR2 or CD14 (an LPS receptor) polymorphisms. ${ }^{43} 44$ It is noteworthy that high exposure to cat allergen reduces the risk of IgE sensitisation and induces an IL10 predominant "modified Th2" response which may represent regulation. ${ }^{45}$ However, such a protective effect of high level allergen exposure is not reported for house dust mite. Much more work is required before exposure to allergen or other factors can be manipulated to prevent allergic sensitisation.

\section{CLINICAL IMPLICATIONS}

How might regulatory $\mathrm{T}$ cells be manipulated or induced for treatment or prevention of asthma? Although CD4+CD25+ T cells do not proliferate in vitro in many systems, it has recently been shown that human cells can be 
expanded in response to antigen ${ }^{46}$ and CD4+CD25+ T cells do proliferate upon in vivo transfer to mice. ${ }^{47}$ It is suggested that suppression by CD4+CD25+ T cells is not antigen specific once these cells are activated, and it might be feasible to transfer cells expanded ex vivo. However, such cell therapy would be complex and potentially hazardous. Another approach is to induce a regulatory population in vivo. Such "adaptive" regulatory $\mathrm{T}$ cells have been described in vivo in mice and in vitro in mice and humans and include a range of subtypes that are distinct from the "naturally occurring" CD4+CD25+ T cells. ${ }^{12}$ For example, IL-10 producing regulatory $\mathrm{T}$ cells were derived in vitro from both human and mouse $\mathrm{T}$ cells by activation in the presence of dexamethasone and vitamin D3 (which inhibit development of Th2 and Thl cells, respectively). ${ }^{48}$ This raises the possibility of inducing similar cells by in vivo allergen exposure in the face of immunosuppressive agents. We recently showed that in vitro exposure of CD4+CD25+ T cells to corticosteroids increased their suppressive activity in subsequent allergen stimulated cultures through increased IL-10 production. ${ }^{49}$ IL-10 producing regulatory $\mathrm{T}$ cell clones were produced by activation in the presence of IL-10: these Trl cells prevented $\operatorname{IgE}$ and Th2 expansion in a mouse model of allergic airways disease but also produced both IL-5 and interferon $\gamma{ }^{50}{ }^{51}$ Animal models of tolerance involving nasal or oral delivery of protein or peptide also induce regulatory $\mathrm{T}$ cell populations-either IL-10 producing $\mathrm{T}$ cells or Th3 cells making TGF $\beta .^{52}{ }^{53}$ For many years allergen injection immunotherapy has been used to control allergic diseases including rhinitis and seasonal asthma, ${ }^{54} 55$ and this treatment produces long lasting clinical effects and a reduction in Th2 responses to allergen exposure. Allergen immunotherapy also induces a predominant IL-10 response to allergen, and this may be associated with development of regulatory $\mathrm{T}$ cells which were CD4+CD25+. ${ }^{5657}$ Whether this phenotype relates to $\mathrm{CD} 4+\mathrm{CD} 25+$ regulatory $\mathrm{T}$ cells or represents activation by allergen remains to be determined, although no difference was found in the suppressive activity of peripheral blood CD4+CD25+ $\mathrm{T}$ cells from hay fever patients who had or had not been treated with immunotherapy. ${ }^{58}$ Allergen immunotherapy is not used for asthma treatment in the UK because of the risk of anaphylaxis, ${ }^{59}$ but a number of modifications may allow its development for asthma. One approach is to break the allergen into short peptides which retain $\mathrm{T}$ cell reactivity but which no longer crosslink $\operatorname{IgE}$ (so it will not trigger anaphylaxis) ${ }^{60}$
This approach shows some efficacy in reducing airway hyperresponsiveness and reduced peripheral blood Th2 responses to allergen, again with an increase in IL-10 production. ${ }^{61}{ }^{62}$ We recently showed that reduced $\mathrm{CD} 4+\mathrm{T}$ cell responses to cat allergen following peptide therapy were not associated with changes in suppression by blood CD4+CD25+ T cells, ${ }^{63}$ so this type of immunotherapy may induce other regulatory $\mathrm{T}$ cell subtypes (or work in another fashion). Other approaches are a combination of immunotherapy with adjuvants such as $\mathrm{CpG}$ oligonucleotides (which activate TLR9) or mycobacterial products. ${ }^{64} 65$ Clearly, it will be important to establish both safety and bystander suppression of other allergens or antigens before these approaches can be used clinically. However, it is interesting that allergen immunotherapy reduced the development of both new allergen sensitisation and of asthma in trials in children with allergic rhinitis, which suggests that immune modulation may hold the potential to prevent asthma. ${ }^{66} 67$

\section{CONCLUSIONS}

Current data support the suggestion that regulatory $\mathrm{T}$ cells may be important in preventing allergic sensitisation in non-allergic individuals. If the balance between regulation and activation of Th2 T cells can be manipulated, this holds great promise for treatment and prevention of asthma. Regulatory $\mathrm{T}$ cells may also be important for a number of other lung diseases: CD4+CD25+ T cells isolated from lung tissue around lung cancers suppressed anti-tumour responses and temporary inactivation of such suppression may be useful for treatment. ${ }^{29}$ It is also possible that airway inflammation in chronic obstructive pulmonary disease results from a failure to suppress $\mathrm{T}$ cell responses to host antigens revealed or altered by smoking or infection. Understanding and manipulation of immune regulation will form a key part in the development of new treatments in coming years.

Thorax 2004;59:640-643.

doi: $10.1136 /$ thx.2003.019166

Correspondence to: Dr D S Robinson, Leukocyte Biology Section, Biomedical Sciences Division, Faculty of Medicine, Sir Alexander Fleming Building, Imperial College London, London SW7 2AZ, UK; d.s.robinson@imperial.ac.uk

DSR is supported in part by a Research Leave Award for Clinical Academics from the Wellcome Trust, UK.

\section{REFERENCES}

1 British Thoracic Society/Scottish Intercollegiate Guidelines Network. British guideline on the management of asthma. Thorax 2003;58(Supp 1):i1-94.
2 Bousquet J. Global initiative for asthma (GINA) and its objectives. Clin Exp Allergy 2000;30(Suppl 1):2-5.

3 Robinson DS, Hamid Q, Ying S, et al. Predominant TH2-like bronchoalveolar Tlymphocyte population in atopic asthma. N Engl J Med 1992;326:298-304.

4 Robinson DS. Th-2 cytokines in allergic disease. Br Med Bull 2000;56:956-68.

5 Busse WW, Lemanske RF Jr. Asthma. NEngl J Med 2001:344:350-62.

6 Sakaguchi S. Regulatory T cells: key controllers of immunologic self-tolerance. Cell 2000;101:455-8.

7 Shevach, EM. CD4+ CD25+ suppressor T cells: more questions than answers. Nat Rev Immunol 2002;2:389-400.

8 Maloy KJ, Powrie F. Regulatory T cells in the control of immune pathology. Nat Immunol 2001;2:816-22.

9 Sakaguchi S, Sakaguchi N, Asano M, et al. Immunologic self-tolerance maintained by activated T cells expressing IL-2 receptor alphachains (CD25). Breakdown of a single mechanism of self-tolerance causes various autoimmune diseases. J Immunol 1995; 155:1151-64.

10 Mottet C, Uhlig HH, Powrie F. Cutting edge: cure of colitis by CD4+CD25+ regulatory T cells. J Immunol 2003;170:3939-43.

11 Jordan MS, Boesteanu A, Reed AJ, et al. Thymic selection of CD4+CD25+ regulatory T cells induced by an agonist self-peptide. Nat Immunol 2001;2:301-6.

12 Bluestone JA, Abbas AK. Natural versus adaptive regulatory T cells. Nat Rev Immunol 2003;3:253-7.

13 Thornton AM, Shevach EM. CD4+CD25+ immunoregulatory $T$ cells suppress polyclonal $T$ cell activation in vitro by inhibiting interleukin 2 production. J Exp Med 1998;188:287-96.

14 Levings MK, Sangregorio R, Roncarolo M-G. Human $\mathrm{CD} 25^{+} \mathrm{CD} 4^{+}$T regulatory cells suppress naive and memory $T$ cell proliferation and can be expanded in vitro without loss of function. J Exp Med 2001; 193:1295-302.

15 Jonuleit $H$, Schmitt E, Stassen M, et al. Identification and functional characterization of human $\mathrm{CD} 4^{+} \mathrm{CD} 25^{+} \mathrm{T}$ cells with regulatory properties isolated from peripheral blood. J Exp Med 2001;193:1285-94.

16 Stephens LA, Mottet C, Mason D, et al. Human $\mathrm{CD} 4(+) \mathrm{CD} 25(+)$ thymocytes and peripheral T cells have immune suppressive activity in vitro. Eur J Immunol 2001;31:1247-54.

17 Dieckmann D, Plottner H, Berchtold S, et al. Ex vivo isolation and characterization of $\mathrm{CD} 4^{+} \mathrm{CD} 25^{+} \mathrm{T}$ cells with regulatory properties from human blood. J Exp Med 2001; 193:303-10.

18 Taams LS, Smith J, Rustin MH, et al. Human anergic/suppressive CD4(+)CD25(+) T cells: a highly differentiated and apoptosis-prone population. Eur J Immunol 2001;31:1122-31.

19 Ng WF, Duggan PJ, Ponchel F, et al. Human $\mathrm{CD} 4(+) \mathrm{CD} 25(+)$ cells: a naturally occurring population of regulatory T cells. Blood $2001 ; 98: 2736-44$

20 Barthlott T, Kassiotis G, Stockinger B. T cell regulation as a side effect of homeostasis and competition. J Exp Med 2003;197:451-60.

21 Maloy KJ, Salaun L, Cahill R, et al. CD4+CD25+ $T(R)$ cells suppress innate immune pathology through cytokine-dependent mechanisms. J Exp Med 2003; 197:111-9.

22 Lloyd CM, Gonzalo JA, Coyle AJ, et al. Mouse models of allergic airway disease. Adv Immunol 2001;77:263-95.

23 Suto A, Nakajima H, Kagami SI, et al. Role of $\mathrm{CD} 4(+)$ CD25(+) regulatory T cells in T helper 2 cell-mediated allergic inflammation in the airways. Am J Respir Crit Care Med 2001;164:680-7.

24 Jaffar Z, Sivakuru T, Roberts K. CD4+CD25+ T cells regulate airway eosinophilic inflammation by modulating the Th2 cell phenotype. J Immunol 2004; 172:3842-9.

25 Hadeiba $\mathbf{H}$, Locksley RM. Lung CD25 CD4 regulatory $T$ cells suppress type 2 immune responses but not bronchial hyperreactivity. $\mathrm{J}$ Immunol 2003;170:5502-10. 
26 Tiemessen MM, Van Hoffen E, Knulst AC, et al. $\mathrm{CD} 4 \mathrm{CD} 25$ regulatory $T$ cells are not functionally impaired in adult patients with lgE-mediated cow's milk allergy. J Allergy Clin Immunol 2001; 1 10:934-6.

27 Bellinghausen I, Klostermann B, Knop J, et al. Human CD4+CD25+ T cells derived from the majority of atopic donors are able to suppress TH1 and TH2 cytokine production. J Allergy Clin Immunol 2003; 111:862-8.

28 ling EM, Smith T, Nguyen XD, et al. Relation of $C D 4+C D 25+$ regulatory $T$-cell suppression of allergen-driven T-cell activation to atopic status and expression of allergic disease. Lancet 2004;363:608-15.

29 Woo EY, Yeh H, Chu CS, et al. Cutting edge: Regulatory $T$ cells from lung cancer patients directly inhibit autologous T cell proliferation. $\mathrm{J}$ Immunol 2002;168:4272-6.

30 Bennett CL, Christie J, Ramsdell F, et al. The immune dysregulation, polyendocrinopathy, enteropathy, X-linked syndrome (IPEX) is caused by mutations of FOXP3. Nat Genet 2001;27:20-1.

31 Brunkow ME, Jeffery EW, Hierrild KA, et al. Disruption of a new forkhead/winged-helix protein, scurfin, results in the fatal ymphoproliferative disorder of the scurfy mouse. Nat Genet 2001;27:68-73.

32 Hori S, Nomura T, Sakaguchi S. Control of regulatory $\mathrm{T}$ cell development by the transcription factor Foxp3. Science 2003;299:1057-61.

33 Fontenot JD, Gavin MA, Rudensky AY. Foxp3 programs the development and function of CD4+CD25+ regulatory T cells. Nat Immunol 2003:4:330-6

34 Khattri R, Cox T, Yasayko SA, et al. An essential role for scurfin in CD4+CD25+ T regulatory cells. Nat Immunol 2003;4:337-42.

35 Walker MR, Kasprowicz DJ, Gersuk VH, et al. Induction of FoxP3 and acquisition of T regulatory activity by stimulated human CD4+CD25- T cells. J Clin Invest 2003;1 12:1437-43.

36 Bruder D, Probst-Kepper M, Westendorf AM, et al. Neuropilin-1: a surface marker of regulatory $T$ cells. Eur J Immunol 2004;34:623-30.

37 O'Garra A. Cytokines induce the development of functionally heterogeneous $\mathrm{T}$ helper cell subsets. Immunity 1998;8:275-83.

38 Eisenbarth SC, Piggott DA, Huleatt JW, et al. Lipopolysaccharide-enhanced, toll-like receptor 4-dependent T helper cell type 2 responses to inhaled antigen. J Exp Med 2002;196:1645-51.

39 Pasare C, Medzhitov R. Toll-like receptors: balancing host resistance with immune tolerance. Curr Opin Immunol 2003;15:677-82.

40 Pasare C, Medzhitov R. Toll pathway-dependent blockade of CD4+CD25+ T cell-mediated suppression by dendritic cells. Science 2003;299: 1033-6.
41 Akbari O, Freeman GJ, Meyer EH, et al. Antigenspecific regulatory $T$ cells develop via the ICOSICOS-ligand pathway and inhibit allergeninduced airway hyperreactivity. Nat Med 2002;8:1024-32.

42 Umetsu DT, Mclntire JJ, Akbari O, et al. Asthma: an epidemic of dysregulated immunity. Nat Immunol 2002:3:715-20.

43 Baldini M, Lohman IC, Halonen M, et al. A polymorphism in the $5^{\prime}$ flanking region of the CD14 gene is associated with circulating soluble CD1 4 levels and with total serum immunoglobulin E. Am J Respir Cell Mol Biol 1999:20:976-83.

44 Eder W, Klimecki W, Yu L, et al. Toll-like receptor 2 as a major gene for asthma in children of European farmers. J Allergy Clin Immunol 2004; 113:482-8.

45 Platts-Mills T, Vaughan J, Squillace S, et al. Sensitisation, asthma, and a modified Th2 response in children exposed to cat allergen: a population-based cross-sectional study. Lancet 2001;357:752-6.

46 Jiang S, Camara N, Lombardi G, et al. Induction of allopeptide-specific human CD4+CD25+ regulatory $T$ cells ex vivo. Blood 2003;102:2180-6.

47 Walker LS, Chodos A, Eggena M, et al. Antigendependent proliferation of CD4+CD25+ regulatory T cells in vivo. J Exp Med 2003; 198:249-58.

48 Barrat FJ, Cua DJ, Boonstra A, et al. In vitro generation of interleukin 10-producing regulatory CD4(+) T cells is induced by immunosuppressive drugs and inhibited by T helper type 1 (Th1)- and Th2-inducing cytokines. J Exp Med 2002; 195:603-16.

49 Robinson DS, Nguyen XD. Fluticasone propionate increases suppression of allergen-driven T cell proliferation by $\mathrm{CD} 4+\mathrm{CD} 25+\mathrm{T}$ cells. J Allergy Clin Immunol 2004;113(suppl): 1190 (abstract).

50 Groux H, O'Garra A, Bigler M, et al. A CD4+ Tcell subset inhibits antigen-specific T-cell responses and prevents colitis. Nature 1997;389:737-42.

51 Cottrez F, Hurst SD, Coffman RL, et al. T regulatory cells 1 inhibit a Th2-specific response in vivo. J Immunol 2000; 165:4848-53.

52 Sundstedt A, O'Neill EJ, Nicolson KS, et al. Role for IL-10 in suppression mediated by peptideinduced regulatory $T$ cells in vivo. $J$ Immunol 2003;170:1240-8.

53 Chen Y, Kuchroo VK, Inobe J, et al. Regulatory T cell clones induced by oral tolerance: suppression of autoimmune encephalomyelitis. Science 1994:265: 1237-40.

54 Durham SR, Walker SM, Varga EM, et al. Longterm clinical efficacy of grass-pollen immunotherapy. N Engl J Med 1999;341:468-75.

55 Walker SM, Pajno GB, Lima MT, et al. Grass pollen immunotherapy for seasonal rhinitis and

asthma: a randomized, controlled trial. J Allergy Clin Immunol 2001;107:87-93.

56 Francis JN, Till SJ, Durham SR. Induction of IL$10+C D 4+C D 25+T$ cells by grass pollen immunotherapy. J Allergy Clin Immunol 2003; 11 1:1255-61.

57 Jutel M, Akdis M, Budak F, et al. IL-10 and TGFbeta cooperate in the regulatory $T$ cell response to mucosal allergens in normal immunity and specific immunotherapy. Eur J Immunol 2003;33:1205-14

58 Ling EM, Calderon M, Nguyen D, et al. Allergen immunotherapy increases suppressive activity by CD4+CD25-, IL-10 producing T cells but does not affect suppression by CD4+CD25+T cells. J Allergy Clin Immunol 2004;113(suppl): 330 (abstract).

59 BSACI Working Party. Position paper on allergen immunotherapy. Clin Exp Allergy 1993;23(Suppl 3): 1-44.

60 Haselden BM, Kay AB, Larche $M$. Immunoglobulin E-independent majo histocompatibility complex-restricted T cell peptide epitope-induced late asthmatic reactions. $J$ Exp Med 1999; 189:1885-94.

61 Oldfield WL, Larche M, Kay AB. Effect of T-cell peptides derived from Fel $\mathrm{d} l$ on allergic reactions and cytokine production in patients sensitive to cats: a randomised controlled trial. Lancet 2002;360:47-53.

62 Oldfield WL, Kay AB, Larche M. Allergen-derived $T$ cell peptide-induced late asthmatic reactions precede the induction of antigen-specific hyporesponsiveness in atopic allergic asthmatic subjects. J Immunol 2001:167:1734-9.

63 Smith TRF, Alexander C, Kay AB, et al. Cat allergen peptide immunotherapy reduces $C D 4^{+} \mathrm{T}$ cell responses to cat allergen but does not alter suppression by $\mathrm{CD} 4^{+} \mathrm{CD} 25^{+} \mathrm{T}$ cells. Allergy 2004 (in press).

64 Tighe H, Takabayashi K, Schwartz D, et al. Conjugation of immunostimulatory DNA to the short ragweed allergen amb a 1 enhances its immunogenicity and reduces its allergenicity. J Allergy Clin Immunol 2000;106:124-34.

65 Zuany-Amorim C, Sawicka E, Manlius C, et al Suppression of airway eosinophilia by killed Mycobacterium vaccae-induced allergenspecific regulatory T-cells. Nat Med 2002;8:625-9.

66 Pajno GB, Barberio G, De Luca F, et al. Prevention of new sensitizations in asthmatic children monosensitized to house dust mite by specific immunotherapy. A six-year follow-up study. Clin Exp Allergy 2001;31:1392-7.

67 Moller C, Dreborg S, Ferdousi HA, et al. Pollen immunotherapy reduces the development of asthma in children with seasonal rhinoconjunctivitis (the PAT-study). J Allergy Clin Immunol 2002;109:251-6.

treatment was inevitably empirical as controlled clinical trials were not possible during the epidemic of this new and serious illness. Many antiviral and immunomodulatory drugs, as well as other treatments such as convalescent patient plasma and traditional Chinese medicines, have been tried. Ribavirin and corticosteroids are by far the most widely used treatments for SARS. In the later phase of the epidemic lopinavir and ritonavir in combination were also used in Hong Kong.

\section{Systematic evaluation of treatment modalities for SARS is still needed}

$\checkmark$ t he epidemic of severe acute respiraory syndrome (SARS) of 2003 caught the medical profession by surprise. The accumulated global total

number of cases was 8098 with 774 deaths, a case-fatality ratio of $9.6 \%{ }^{1}$ Although the novel coronavirus (SARS$\mathrm{CoV})$ was discovered within weeks, ${ }^{2}$

\section{ANTIVIRAL AGENTS \\ Ribavirin}

Ribavirin is used extensively for the treatment of SARS and was given to over $90 \%$ of patients in Hong Kong. It is a nucleoside analogue that has activity against a number of DNA and RNA 
viruses in vitro. ${ }^{3}$ The mechanism of action of ribavirin has been studied for decades and is still under active debate. ${ }^{4}$ In early March 2003, before the isolation of the SARS-CoV, many experts believed that the mysterious severe illness was due to an unknown virus and ribavirin was empirically given because of its broad spectrum antiviral activity. Furthermore, corticosteroids were increasingly prescribed for the treatment of SARS and some believed that such treatment would be dangerous if not covered with an antiviral agent. The published reports on the effectiveness of ribavirin were mostly retrospective case series with intrinsic methodological issues and it is difficult to draw conclusions. The major side effect of ribavirin is anaemia which occurs in $27-59 \%$ of patients. $^{5-9}$ Anaemia reduces oxygen transport and potentiates the existing problem of oxygenation and tissue hypoxia. Other significant side effects include raised transaminases and bradycardia, ${ }^{5}$ as well as hypocalcaemia, hypomagnesaemia, and risk of teratogenicity. ${ }^{10}$ In a detailed study on the clinical course and viral load, Peiris et $a l^{11}$ reported that 14 patients given a standard regimen of ribavirin and steroids showed a peak viral load at day 10 from onset of illness. This study, although involving a small number of subjects, clearly indicated the inability of ribavirin to clear SARS-CoV from patients with SARS. The result of this study also explained why patients treated with ribavirin early in the illness were able to infect healthcare workers when they subsequently required endotracheal intubation. The lack of in vitro activity of the drug against SARS-CoV ${ }^{12-14}$ cast further doubts on the usefulness of ribavirin in SARS. The use of ribavirin in SARS has been reviewed elsewhere. ${ }^{15} 16$

\section{Lopinavir and ritonavir}

Lopinavir and ritonavir (LPV/r) are protease inhibitors which, in combination, have been licensed for the treatment of HIV disease. Ritonavir has little antiviral activity and its role is to inhibit CYP3A mediated metabolism of lopinavir, thus increasing the serum concentration of lopinavir. In the laboratory lopinavir and ribavirin have significant synergism in inhibiting SARS- $\mathrm{CoV}^{6}$ and, on that basis, this combinationtogether with steroids-have been used in some centres in Hong Kong since mid April 2003. In this retrospective study the authors found that the 12 patients who received early treatment with LPV/r together with ribavirin and steroids had significantly fewer 21 day adverse clinical outcomes (acute respiratory distress syndrome or death) than 111 historical controls receiving ribavirin and steroids.
Other benefits of the LPV/r group included favourable viral load profiles (in six patients), early rise of lymphocyte counts, and a reduced need for "rescue" pulse steroid doses. Adverse events attributable to LPV/r were minimal. Similar findings were reported in a case controlled study involving more patients from Hong Kong. ${ }^{17}$ Randomised controlled trials are being planned in Hong Kong to confirm these results should SARS re-emerge.

\section{CORTICOSTEROIDS}

Corticosteroids have been used widely to treat SARS, first in mainland China and then in Hong Kong. The main rationale for their use in SARS is that, in acute viral respiratory infections, early response cytokines such as interferon gamma (IFN- $\gamma)$, tumour necrosis factor, interleukin 1 (IL-1), and interleukin 6 (IL-6) contribute to tissue injury, ${ }^{18} 19$ and corticosteroid treatment may suppress the "cytokine storm". ${ }^{20}$ Peiris et al hypothesised that the clinical worsening often observed during the second phase of illness is the result of immunopathological damage from an overexuberant host response. ${ }^{13}$ In a newly published report Wong et $a^{21}$ showed in 20 consecutive adults with SARS that there was a marked increase in the Thl cytokine IFN- $\gamma$, inflammatory cytokines IL-1, IL-6, and IL-12 for at least 2 weeks after disease onset. The chemokine profile showed a significant increase in IL-8, monocyte chemoatttractant protein-1 (MCP-1), and IFN- $\gamma$ inducible protein-10 (IP-10). Corticosteroids significantly reduce IL-8, MCP-1, and IP- 10 concentrations 5-8 days after treatment. The data confirmed the Thl cell mediated immunity and hyperinnate inflammatory response in SARS through the accumulation of monocytes/macrophages and neutrophils. Another rationale for use of steroids in SARS is the necroscopic finding of features of acute respiratory distress syndrome (ARDS), ${ }^{22} 23$ and there have been reports of successful use of steroids in the treatment of $\mathrm{ARDS}^{24}$ and septic shock. ${ }^{25}$ In addition, systemic steroids have been used in the treatment of some infections with variable success. ${ }^{26-29}$ On the other hand, the potential for corticosteroids to suppress the innate host defence against SARS-CoV resulting in increased viral replication has to be considered. Chu et al reported an increase in viral load in one patient following pulse methylprednisolone therapy. ${ }^{6}$ Increased replication of other respiratory viruses has also been reported following steroid therapy. ${ }^{26}{ }^{30-32}$

Whereas "low dose" steroids at 0.5$1.0 \mathrm{mg} / \mathrm{kg} /$ day prednisolone (or equivalent) have been used in infections,
ARDS and septic shock, "pulse doses" at $\quad 0.5-1.0 \mathrm{~g} /$ day methylprednisolone have generally not been recommended for these conditions but were used extensively in SARS, particularly in the second week of illness when patients often show acute clinical deterioration. The efficacy of pulse steroids in SARS remains to be determined, but it is conceivable that higher steroid doses will result in a higher incidence and severity of side effects.

Published case series examining the clinical efficacy of steroid treatment in SARS $^{79}{ }^{33-40}$ suffer the same methodological problems as those of ribavirin. In addition, there is a wide variety of steroid dosing schedules making retrospective analysis of steroid efficacy exceptionally difficult. There is so far no systematic review of the efficacy of corticosteroid treatment in SARS based on the numerous published studies. Some investigators do feel that judicious use of corticosteroids is beneficial, but randomised controlled studies are needed to confirm the beneficial effects as well as to give insight into the optimal regimen. The possible beneficial effects, however, have to be balanced against the significant side effects including nosocomial infections, ${ }^{794041}$ hyperglycaemia, hypokalaemia, hypertension, and gastrointestinal haemorrhage. $^{7-9}$ Avascular necrosis of bone (AVN) is perhaps the most distressing medium term side effect of steroids in patients with SARS. Preliminary data on a cohort of 330 adult patients from Princess Margaret Hospital, Hong Kong who received various doses of steroids and in whom magnetic resonance imaging was performed at an average of 7.5 months from illness onset showed that AVN was present in 48 of them (14.5\%, (unpublished data). Of the 48 , $16(33 \%)$ had unilateral involvement of the femoral head and $19(40 \%)$ had bilateral involvement of the femoral head. Univariate analysis showed that the total steroid dose was significantly associated with development of AVN (unpublished data).

\section{CONCLUSIONS}

As SARS has only recently appeared and a limited number of patients have been managed in different locations, it is understandable that there has been a lack of systematic and critical evaluation of treatment in the form of randomised controlled trials. Nonetheless, the enormous effort that researchers put into looking for effective treatments for SARS is highly commended. The recent re-emergence of SARS did not result in secondary spread, but is nevertheless a reminder that it could strike again. What may be even more threatening 
is the deadly avian influenza A ( $\mathrm{H} 5 \mathrm{Nl}$ ) which has repeatedly demonstrated its ability to infect humans, and may acquire the ability for efficient human to human transmission in the future. It is hoped that, when epidemics of new disease strikes, a systematic way of evaluating treatment modalities would be in place to provide answers to important questions in the shortest possible time.

Thorax 2004;59:643-645.

doi: $10.1136 /$ thx. 2003.017665

\section{Authors' affiliations}

W C Yu, Department of Medicine \&

Geriatrics, Princess Margaret Hospital, Hong

Kong Special Administrative Region, China

D S C Hui, Faculty of Medicine \&

Therapeutics, The Chinese University of Hong

Kong, Hong Kong Special Administrative

Region, China

M Chan-Yeung, Faculty of Medicine, The University of Hong Kong, Hong Kong Special

Administrative Region, China

Correspondence to: Dr W C Yu, Department of Medicine, Princess Margaret Hospital, Lai King, Hong Kong SAR, China; yuwc@ha.org.hk

\section{REFERENCES}

1 World Health Organization: SARS: cumulative number of reported probable cases. http:// www.who.int/csr/sars/country/en/ (accessed 24 January 2004)

2 Ksiazek TG, Erdman D, Goldsmith CS, et al. A novel coronavirus associated with severe acute respiratory syndrome. N Engl J Med 2003;348:1953-66.

3 Sidwell RW, Huffman JH, Khare GP, et al. Broadspectrum antiviral activity of virazole: 1-beta-Dribofuranosyl-1,2,4-triazole-3-carboxamide. Science 1972;177:705-6.

4 Cameron $\mathrm{CE}$, Castro $\mathrm{C}$. The mechanism of action of ribavirin: lethal mutagenesis of RNA virus genomes mediated by the viral RNA-dependent RNA polymerase. Curr Opin Infect Dis 2001:12:261-72.

5 Booth CM, Matukas LM, Tomlinson GA, et al. Clinical features and short term outcomes of 144 patients with SARS in the greater Toronto area. JAMA 2003;289:2801-9.

6 Chu CM, Cheng VC, Hung IF, et al. The role of lopinavir/ritonavir in the treatment of SARS: initial virological and clinical findings. Thorax 2004:59:252-6

7 Chan JWM, Ng CK, Chan YH, et al. Short term outcome and risk factors for adverse clinical outcomes in adults with severe acute respiratory syndrome. Thorax 2003:58:686-9.

8 Choi KW, Chau TN, Tsang O, et al. Outcomes and prognostic factors in 267 patients with severe acute respiratory syndrome in Hong Kong. Ann Intern Med 2003; 139:715-23.

9 Sung JJ, Wu A, Joynt GM, et al. Severe acute respiratory syndrome: report of treatment and outcome after a major outbreak. Thorax 2004;59:414-20.

10 Knowles SR, Phillips EJ, Dresser L, et al. Common adverse events associated with the use of ribavirin for severe acute respiratory syndrome. Clin Infect Dis 2003;37: $1139-42$

11 Peiris JS, Chu CM, Cheng VC, et al. Clinical progression and viral load in an outbreak of coronavirus-associated SARS pneumonia: a prospective study. Lancet 2003;361:1767-72.

12 Huggins JW. Severe acute respiratory syndrome (SARS) and coronavirus testing-United States. MMWR 2003:52:297-302.

13 Health Canada. Management of severe acute respiratory syndrome (SARS) in adults: Interim guidance for healthcare providers, http:// www.hc-sc.gc.ca/(accessed 24 January 2004).

14 Cinatl J, Morgenstern B, Baver G, et al. Glycyrrhizin, an active component of liquorice roots, and replication of SARS-associated coronavirus. Lancet 2003:361:2045-6.

15 van Vonderen MGA, Bos JC, Prins JM, et al. Ribavirin in the treatment of severe acute respiratory syndrome (SARS). Neth J Med 2003:61:238-41.

16 Zhaori G. Antiviral treatment for SARS: can we draw any conclusions? Can Med Assoc J 2003;169:1165-6.

17 Chan KS, Lai ST, Chu CM, et al. Treatment of severe acute respiratory syndrome with lopinavir/ ritonavir: a multicentre retrospective matched cohort study. Hong Kong Med J 2003:9:399-406

18 Van Reeth K, Van Gucht S, Penseart M Correlations between lung proinflammatory cytokine levels, virus replication, and disease after swine influenza virus challenge of vaccinationimmune pigs. Viral Immunol 2002; 15:583-94.

19 Cheung CY, Poon LL, Lau AS, et al. Induction of proinflammatory cytokines in human macrophages by influenza $A(H 5 N 1)$ viruses: a mechanism for the unusual severity of human disease? Lancet 2002;360:1831-7.

20 Lee N, Sung J. The use of corticosteroids in SARS. N Engl J Med 2003;348:2034-5.

21 Wong CK, Lam CKW, Wu AKL, et al. Plasma inflammatory cytokines and chemokines in severe acute respiratory syndrome. Clin Exp Immunol 2004; 136:95-103.

22 Nicholls JM, Poon LL, Lee KC, et al. Lung pathology of fatal severe acute respiratory syndrome. Lancet 2003;361:1773-8.

23 Franks TJ, Chong PY, Chui P, et al. Lung pathology in severe acute respiratory syndrome (SARS): a study of 8 autopsy cases in Singapore. Hum Pathol 2003:34:743-8.

24 Meduri GU, Headley AS, Golden E, et al. Effect of prolonged methylprednisolone therapy in unresolving acute respiratory distress syndrome: a randomized controlled trial. JAMA 1998;280:159-65.
25 Keh D, Boehnke T, Weber-Cartens S, et al. Immunologic and hemodynamic effects of "low dose" hydrocortisone in septic shock. Am J Respir Crit Care Med 2003;167:512-20.

26 Buckingham SC, Jafri HS, Bush AJ, et al. A randomized, double-blind, placebo-controlled trial of dexamethasone in severe respiratory syncytial virus (RSV) infection: effects on RSV quantity and clinical outcome. $J$ Infect Dis 2002; 185: 1222-8

27 Pareja JG, Garland R, Koziel H. Use of adjunctive corticosteroids in severe adult non-HIV Pneumocystis carinii pneumonia. Chest 1998;113:1215-24.

28 Smego RA, Ahmed N. A systematic review of the adjunctive use of systemic corticosteroids for pulmonary tuberculosis. Int J Tuberc Lung Dis 2003:7:208-13.

29 Wormser GP, Horowitz H, Dworkin B. Low-dose dexamethasone as adjunctive therapy for disseminated Mycobacterium avium complex infections in AIDS patients. Antimicrob Agents Chemother 1994:38:2215-7.

30 Gustafson LM, Proud D, Hendley JO, et al. Oral prednisone therapy in experimental rhinovirus infection. J Allergy Clin Immuno 1996:97:1009-14.

31 Domachowske JB, Bonville CA, Ali-Ahmad D, ef al. Glucocorticoid administration accelerates mortality of pneumovirus-infected mice. J Infect Dis 2001 ; 184:1518-23.

32 Puhakka T, Makela MJ, Malmstrom, K, et al. The common cold: effects of intranasal fluticasone propionate treatment. J Allergy Clin Immunol 1998; 101:726-31.

33 Tsang KW, Ho PL, Ooi GC, et al. A cluster of cases of acute severe respiratory syndrome in Hong Kong. N Engl J Med 2004;348:1977-85

34 Lee N, Hui D, Wu A, et al. A major outbreak of severe acute respiratory syndrome in Hong Kong. N Engl J Med 2003;348:1986-94.

35 So LK, Lau AC, Yam LY, et al. Development of a standard treatment protocol for severe acute respiratory syndrome. Lancet 2003:361:1615-7.

36 Zhao Z, Zhang F, Xu M, et al. Description and early treatment of an early outbreak of severe acute respiratory syndrome (SARS) in Guangzhou, PR China. J Med Microbiol 2003:52:715-20.

37 Ho JC, Ooi GC, Mok TY, et al. High-dose pulse versus nonpulse corticosteroid regimens in severe acute respiratory syndrome. Am J Respir Crit Care Med 2003;168:1449-56.

38 Tsui PT, Kwok ML, Yuen H, et al. Severe acute respiratory syndrome: clinical outcomes and prognostic correlates. Emerg Infect Dis 2003:9:1064-9.

39 Wu W, Wang J, Liu P, et al. A hospital outbreak of severe acute respiratory syndrome in Guangzhou, China. Chin Med J 2003; 16:811-8

40 Li N, Ma J, Nie L, et al. Retrospective analysis of corticosteroid treatment in severe acute respiratory syndrome (SARS). Beijing Da Xue Xue Bao 2003;35(Suppl): 16-18.

41 Wang $H$, Ding $Y$, Li $X$, et al. Fatal aspergillosis in a patient with SARS who was treated with corticosteroids. N Engl J Med 2003;349:507-8. 